RASĀYAN J. Chem.

Vol. 12 | No. 2 |494 - 501| April - June | 2019

ISSN: 0974-1496 | e-ISSN: 0976-0083 | CODEN: RJCABP

http://www.rasayanjournal.com

http://www.rasayanjournal.co.in

\title{
THE APPLICATION OF CHITOSAN MODIFIED POLYURETHANE FOAM ADSORBENT
}

\author{
Marlina $^{1,}$, M. Iqhrammullah ${ }^{1}$, Darmadi $^{2}$, I. Mustafa ${ }^{1}$ and Rahmi ${ }^{1}$ \\ ${ }^{1}$ Department of Chemistry, Universitas Syiah Kuala, Faculty of Mathematics and Natural \\ Sciences, Kopelma Darussalam, 23111, (Banda Aceh) Indonesia. \\ ${ }^{2}$ Department of Chemical Engineering, Universitas Syiah Kuala, Faculty of Mathematics and \\ Natural Sciences, Kopelma Darussalam, 23111, (Banda Aceh) Indonesia. \\ *E-mail : marlina@unsyiah.ac.id
}

\begin{abstract}
This study is the continuation of our previous work on the synthesized chitosan modified polyurethane foam (ChiPUF) adsorbent by using a simple method. This research aims to examine the isotherm adsorption of Chi-PUF and its direct application on mercury-contaminated well water samples from Aceh Jaya regency. Two common Langmuir and Freundlich isotherm models were used in these studies. Adsorption test with the variation of initial adsorbate concentration was carried out for the isotherm studies. The test was carried out under the predetermined optimum conditions (60 minutes of contact time and $\mathrm{pH} 7$ ). $\mathrm{Hg}$ (II) adsorption using Chi-PUF fits the Freundlich isotherm model with R-value to be the closest one to 1 (0.9417).Even though the value of adsorption constant ( $\mathrm{K}_{\mathrm{f}}$ ) was not high $(0.2968(\mathrm{mg} / \mathrm{g})(\mathrm{L} / \mathrm{mg}))$, Chi-PUF adsorbent was able to adsorb $\mathrm{Hg}$ from the well water samples up to $83.049 \%$.
\end{abstract}

Keywords: Polyurethane Foam, Chitosan, Mercury, Adsorption, Isotherm, Langmuir, Freundlich

(C) RASĀYAN. All rights reserved

\section{INTRODUCTION}

As many as $62 \%$ of the water resources in Aceh Jaya regency are polluted with mercury, reported by the Public Health Office ${ }^{1}$. The mercury was found to exceed the threshold concentration (1 ppb for drinking water and $2 \mathrm{ppb}$ for daily use) which has been determined by the government in the presidential decree number 82 the year 2001.The indication of mercury poisoning was shown by 13 cases of infant's death and defectiveness in the watershed area of Keudu Panga District, Aceh Jaya Regency ${ }^{2}$. This is an urgent and serious problem which needs an immediate solution.

To remove mercury from aqueous solution, chemical treatment such as adsorption can be employed. Polymeric materials have obtained much attention due to their promising properties for wastewater treatment and $\mathrm{Hg}$ removal $^{3}$. Polymeric materials which possess polar and non-polar groups are important for adsorption. Polyurethane foam (PUF) is a polymer that has both polar and non-polar groups, therefore, can adsorb a variety of chemical substances. Hong, et al., reported that PUF can separate free molecules, aromatic compounds, dithionate metals, and complex anoins ${ }^{4}$. Furthermore, Liu, et al., reported that PUF can be synthesized out of castor oil as the polyols ${ }^{5}$. Not only because of its eco-friendly properties, such as the economic value, biodegradability and low toxicity, castor oil is superior in polyurethane synthesis due to the presence hydroxyl group in ricinoleic acid chain allowing the formation of urethane groups.

PUF can be integrated with potential fillers, both organic and inorganic, to increase its adsorption capacity and selectivity. Khan, et al., has succeeded to modify PUF with multiwalled carbon nanotube for its application to remove safranin T and P (II) ${ }^{6}$. Moawed, et al., has integrated halogen atom and amine groups to PUF to adsorb Bi (III), Co (II), Fe (III), and Mo (III) ${ }^{7}$. The successful modification has also been reported by Riaz, et al., where PUF was modified with acetic cellulose to adsorb $\mathrm{Cr}(\mathrm{VI})^{8}$.

In the previous research, we have succeeded synthesizing Chitosan modified PUF to be used as an adsorbent for Hg (II) removal. The SEM characterization of the synthesized PUF showed the irregular-

Rasayan J. Chem., 12(2), 494-501(2019)

http://dx.doi.org/10.31788/RJC.2019.1225080

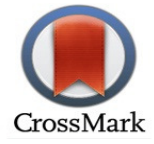


sized and multilayer pores. Meanwhile, the DSC characterization described the rigidity of PUF, where the $\mathrm{Tg}$, Tc and Tm respectively are 280,310 and $399{ }^{\circ} \mathrm{C}$. The chitosan optimal composition was $2.5 \%$ of total initial materials weight, exhibited by the adsorption capacity of $0.59 \mathrm{mg} / \mathrm{g}^{9}$. The adsorption isotherm studies of PUF and its application in well water samples is further conducted in this research.

\section{Material and Methods}

\section{EXPERIMENTAL}

This research was performed in the Research Laboratory of Chemical Department of Mathematics and Natural Sciences Faculty, Syiah Kuala University. The materials were Chi-PUF, $\mathrm{HgCl}_{2}$, well water sample, distilled water, $\mathrm{HCl}$ and $\mathrm{KOH}$. Chi-PUF was prepared and has been discussed in our previous report ${ }^{9}$. Artificial mercury (II) sample was prepared by dissolving $\mathrm{HgCl}_{2}$ into distilled water. Well, water samples were collected from 3 sampling points in Aceh Jaya regency (see Table-3). Mercury concentration was determined with Atomic Absorption Spectroscopy (AAS, Shandon Southern A3400).

\section{The Determination of Optimum Chitosan Ratio}

Chi-PUF which had been synthesized ${ }^{9}$, was cut into $5 \mathrm{~cm}^{3}$ cubical shape. $25 \mathrm{~mL} \mathrm{Hg}$ (II) solution was poured into an Erlenmeyer, followed by 1 gram Chi-PUF adsorbents. After being stirred continuously at $420 \mathrm{rpm}$ for 1 hour, $600 \mu \mathrm{L}$ of the solution was taken and dissolved in $140 \mathrm{~mL}$. The final concentration of $\mathrm{Hg}$ (II) ions was then determined by using AAS. The difference between the initial and final concentration of $\mathrm{Hg}$ (II) ions showed the number of adsorbed $\mathrm{Hg}$ (II) ions. This was done for every ChiPUF with different chitosan ratio of $0 \%, 2.5 \%, 0.5 \%, 7.5 \%$ and $10 \%$. In order to obtain the adsorption capacity and removal percentage, the following equations were used:

$$
\begin{gathered}
q(t)=\frac{\left[C_{0}-C_{t}\right] V}{m} \\
P_{r}=\frac{\left[C_{0}-C_{e}\right]}{C_{0}} \times 100
\end{gathered}
$$

Where, $\mathrm{q}$ refers to the adsorption capacity $(\mathrm{mg} / \mathrm{g})$, meanwhile, $\operatorname{Pr}$ is removal percentage. $C_{0}$ and $C_{t}$ respectively are initial concentration and finathe 1 concentration of the solution at $t$ time $(\mathrm{mg} / \mathrm{L})$, $V$ is the volume of the solution (L) and $m(\mathrm{~g})$ is the weight of the adsorbent.

\section{The Determination of Optimal Contact Time}

Adsorption was performed by preparing 1 gram of $0.5 \mathrm{~cm}^{3}$ cubical Chi-PUF in 5 beakers $(250 \mathrm{~mL})$, each contained $25 \mathrm{~mL} \mathrm{Hg}$ (II) $5 \mathrm{ppm}$ solution. After being left at the speed of $420 \mathrm{rpm}$ with for the variation of contact times ranged from 5 to 90 minutes until the adsorption equilibrium reached. By using AAS, the concentration of $\mathrm{Hg}$ (II) in the solution was then calculated with the stated procedure.

\section{The Determination of Optimal pH}

1 gram of $0.5 \mathrm{~cm}^{3}$ cubical Chi-PUF was added in each of 7 beakers $(250 \mathrm{~mL})$ containing $25 \mathrm{~mL} \mathrm{Hg}$ (II) solution at an initial concentration of $5 \mathrm{ppm}$. The mixture was stirred at room temperature, $420 \mathrm{rpm}$ of stirring speed and $\mathrm{pH}$ range of $3-9$ for 60 minutes (optimal contact time). $\mathrm{HCl}$ and $\mathrm{KOH}$ were used to adjust the $\mathrm{pH}$. Then, the solution was filtered and $600 \mu \mathrm{L}$ of the solution was dissolved in $140 \mathrm{~mL}$ distilled water. By using AAS, the concentration of $\mathrm{Hg}$ (II) in the solution was then calculated with the stated procedure.

\section{Hg (II) Ions Adsorption with Concentration Variation at Optimal Contact Time and pH}

1 gram of $0.5 \mathrm{~cm}^{3}$ cubical Chi-PUF was added in each of 5 beakers $(250 \mathrm{~mL})$ containing $25 \mathrm{~mL} \mathrm{Hg}$ (II) solution with initial concentration variation of $5 \mathrm{ppm}, 10 \mathrm{ppm}, 15 \mathrm{ppm}, 20 \mathrm{ppm}$, and $25 \mathrm{ppm}$. The mixture was stirred at room temperature, $420 \mathrm{rpm}$ of stirring speed and $\mathrm{pH} 6$ (optimal $\mathrm{pH}$ ) for 60 minutes (optimal contact time). $\mathrm{HCl}$ and $\mathrm{KOH}$ were used to adjust the $\mathrm{pH}$. By using $\mathrm{AAS}$, the concentration of $\mathrm{Hg}$ (II) in the solution was then calculated with the stated procedure. 


\section{Adsorption Isotherm Studies}

\section{RESULTS AND DISCUSSION}

The adsorbent samples (Chi-PUF) used in this study has been previously manufactured as reported by Darmadi, et al. ${ }^{9}$ Chi-PUF was synthesized by mixing castor oil as the polyol source and toluene diisocyanate (TDI) as the isocyanate source with $\mathrm{OH} / \mathrm{NCO}$ ratio of $1: 0.5$ (gram/gram).PUF itself, can be applied as an adsorbent due to its possession of amine and hydroxyl groups which act as binding sites to interact with the adsorbates ${ }^{8}$. Chitosan was then employed as the filler, added during the polymerization. This addition of chitosan as a filler is due to the fact that chitosan's ability to adsorb heavy metal, including mercury.

Dulazi reported that the same amine groups can also be found at chitosan molecules, thus chitosan addition as a filler in PUF matrix, increased its adsorption capacity ${ }^{10}$. It can be observed through the increase of adsorption capacity of Chi-PUF, however the addition of chitosan for more than $2.5 \%$, as shown by Fig.-1, reduced the adsorption capacity ${ }^{9}$.According to the results obtained, the adsorption capacity values of Chi-PUF with different ratio of Chitosan $(0 \%, 2.5 \%, 5 \%, 7.5 \%$ and $10 \% \mathrm{w} / \mathrm{w}$ mixture A) are $0.28,0.59,0.51,0.48$ and $0.45 \mathrm{mg} / \mathrm{g}$, where $\mathrm{Hg}$ (II) removal percentage reached $22.50 \%, 46.83 \%$, $41.01 \%, 38.74 \%$ dan $35.74 \%$.

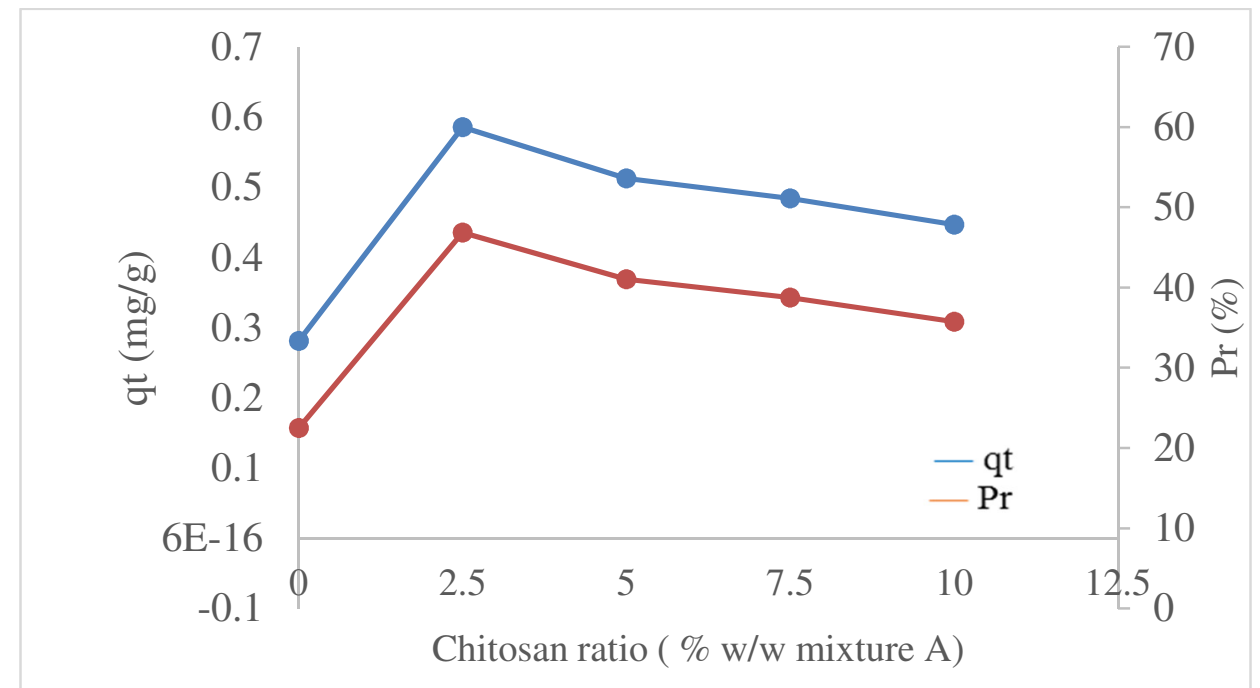

Fig.-1: The Effect of Chitosan Addition into Chi-PUF Matrix against its Adsorption Capacity (qt) and the Percentage Removal of $\mathrm{Hg}$ (II) (Pr).

This is in line with Hussein's report, where the addition of iron oxide nanoparticle filler in a certain amount could reduce the adsorption capacity on arsenic metal ${ }^{11}$. The comparable result was reported by Kong, et al., where the coal filler addition in PUF matrix for more than $4 \%$ could reduce the adsorption capacity ${ }^{12}$. This is agreed by Pinto, as he reported that the properties, as well as the particle size of the filler, affect the modified PUF's adsorption ability ${ }^{13}$.Therefore, it can be assumed that the addition of chitosan more than $2.5 \%$ (w/w mixture A) could reduce the capacity of Chi-PUF to adsorb Mercury (II) ions as the consequence of the chitosan aggregates formation, blocking the binding sites.

\section{Optimum Contact Time Analysis}

One of the important parameters to be determined in adsorption isotherm studies is optimum adsorption contact time.The adsorption efficiency can also be observed by the optimum contact time parameter, where the optimum result is expected to obtain in a short time.Therefore, to calculate the optimum contact time,the adsorption time was varied from 5 minutes, 10 minutes, 15 minutes, 30 minutes, 45 minutes, 60 minutes, 90 minutes and 120 minutes. The initial concentration and $\mathrm{pH}$ used in this test respectively are 5 ppm and $4 \mathrm{ppm}^{14,15}$. The adsorption test of $\mathrm{Hg}$ (II) ion by Chi-PUF with the contact time variation can be observed in Fig.-2. 
The increase of adsorption capacity was in line with the increase of contact time, and went constant at 60 minutes of contact time as shown in Fig.-2. The adsorption process went slowly between 5 minutes up to 45 minutes of contact time. The slow process of adsorption is due to the progress of the adsorbate to be adsorbed through Chi-PUF's pores, especially where the Chi-PUF has a closed cell property. Meanwhile, the adsorption runs faster after the $60^{\text {th }}$ minute contact time and went near to the equilibrium afterward. The fast adsorption process is due to the electrostatic attraction between the unoccupied adsorption sites and the adsorbates. The adsorption between $60^{\text {th }}$ to $90^{\text {th }}$ minute happened through diffusion so that close to the equilibrium, it is due to the saturated adsorption sites. Thus, the 60-minute contact time was selected as the optimum contact time for Mercury (II) adsorption.

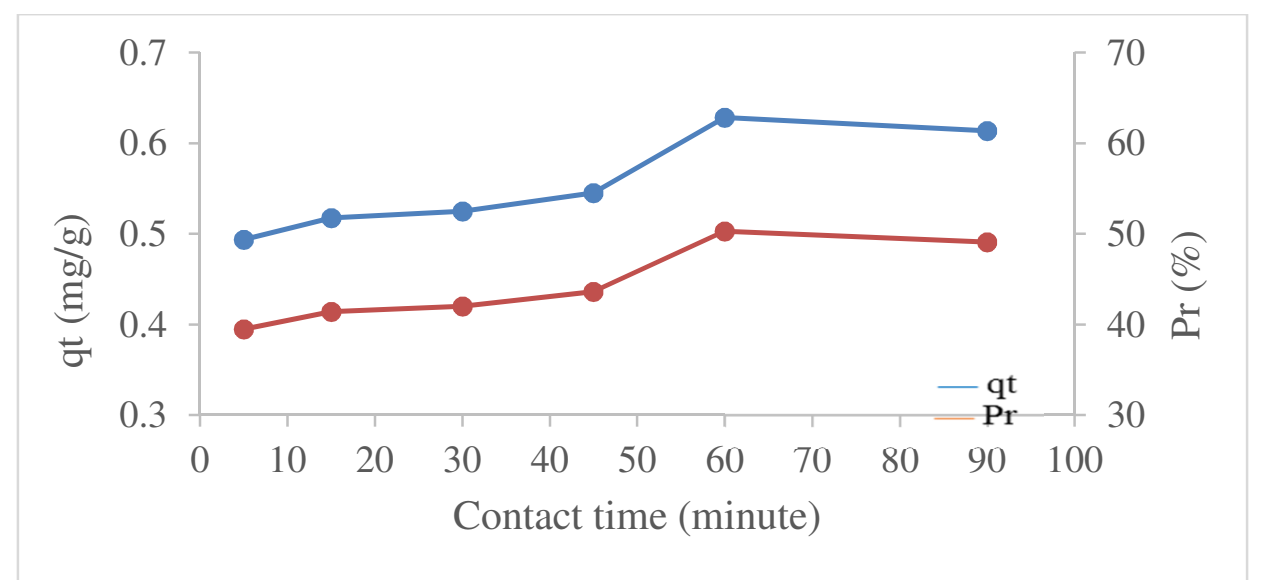

Fig.-2: The Adsorption Capacity (qt) and the Removal Percentage (Pr) in Different Contact Times

\section{Optimum Initial pH Analysis}

Optimization of adsorption condition for $\mathrm{Hg}$ (II) ion can be accomplished by acidity control. Influence of $\mathrm{pH}$ towards the adsorption process can be explained by the disturbance of electrostatic force and the presence of $\mathrm{H}^{+}$and $\mathrm{OH}^{-}$which may act as the competing ions with $\mathrm{Hg}$ (II) ions. Optimum $\mathrm{pH}$ determination was conducted with a $\mathrm{pH}$ variation range of 3 to 9 , considering the possibility of the dissolved chitosan under the $\mathrm{pH} \mathrm{3}$, and also the precipitation of $\mathrm{Hg}$ metal when the $\mathrm{pH}$ is above 9. The graphic of the optimum $\mathrm{pH}$ determination can be observed through Fig.-3.

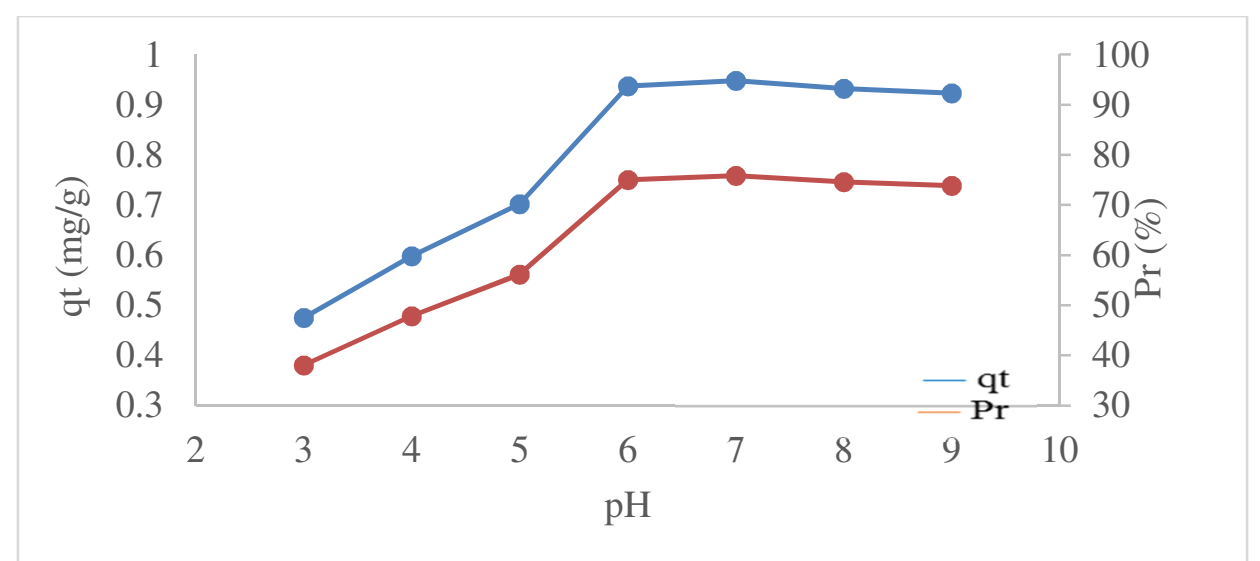

Fig.-3: The Effect of Solution Acidity (indicated by $\mathrm{pH}$ ) on the Adsorption Capacity of Chi-PUF and the Removal Percentage of Hg (II) Ions

The Chi-PUF adsorbents in acid $\mathrm{pH}(<7)$ tend to form positive charge in the surface, due to the protonation of amine group which can be found on each polyurethane and chitosan chain. Because of the positive charge foam surface, thus its adsorption capacity was reduced due to the existence of electrostatic repelling force. Meanwhile, at $\mathrm{pH} 7$, the Chi-PUF surface tends to possess negative charge and attract $\mathrm{Hg}$ 
which has been majorly formed in the positively charged species ${ }^{16}$. The depletion of adsorption capacity at $\mathrm{pH}$ above 7 is caused by the metal precipitation as explained by Huang, et al. ${ }^{15}$. Besides, the competition with $\mathrm{H}^{+}$ions in acidic condition and $\mathrm{OH}^{-}$ions in basic condition, is able to reduce Chi-PUF's adsorption capacity against Mercury (II) ions.

\section{Chi-PUF Adsorption of Hg (II) Ions with Different Concentrations at the Optimum Contact Time and $\mathbf{p H}$.}

Langmuir and Freundlich adsorption isotherm are the two most common models used in the adsorption isotherm studies ${ }^{17,18}$. Both of the isotherm models have been used to identify the maximum adsorption capacity of Chi-PUF for mercury ions. To receive the equation of the adsorption isotherms, the adsorption test has been conducted with initial $\mathrm{Hg}$ (II) concentration of 5 ppm, 10 ppm, 15 ppm, 20 ppm and 25 ppm on optimum contact time of 60 minutes and $\mathrm{pH} 7$.

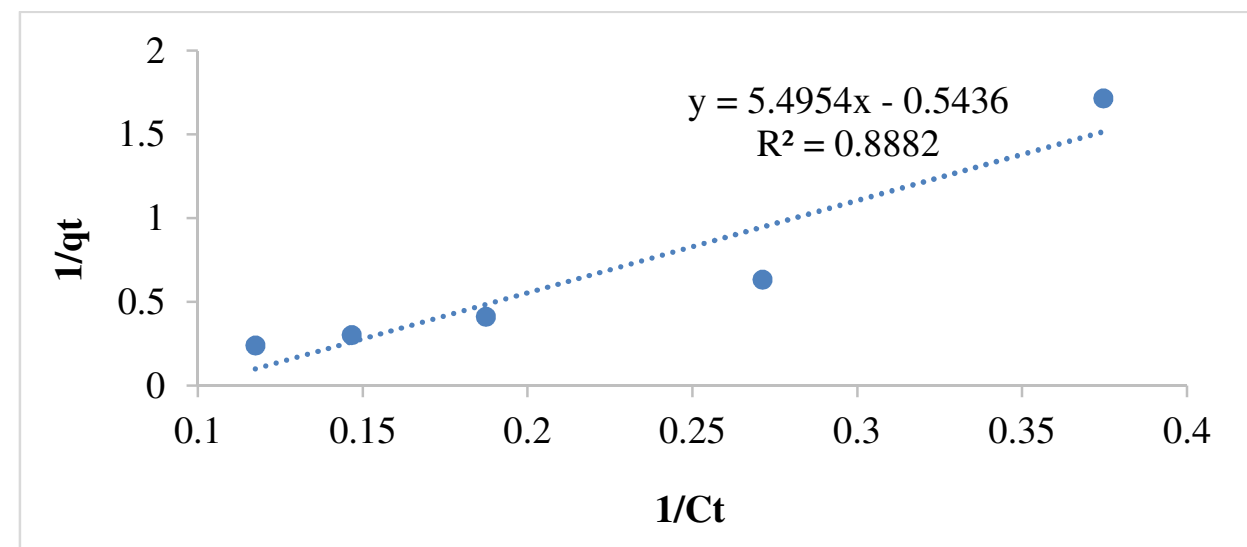

Fig.-4: Langmuir Isotherm Model for Chi-PUF Adsorption of Hg (II) Ions

A straight-line equation of Langmuir isotherm curve ( $\mathrm{y}=5.4954 \mathrm{x}-0.5436$ and $\mathrm{R}^{2}=0.8882$ ) is observable in Fig.-4. To calculate the values of $\mathrm{x}$ and $\mathrm{y}$, the below equation was used:

$$
\frac{1}{q}=\frac{1}{q_{\max }}+\frac{1}{K_{a} q_{\max } C}
$$

Where q refers to the total milligrams of adsorbates of each gram adsorbent $(\mathrm{mg} / \mathrm{g}), \mathrm{C}$ is the metal ions concentration left in the solution ( $\mathrm{mg} / \mathrm{g}), \mathrm{q}_{\max }$ is the maximum monolayer adsorption value $(\mathrm{mg} / \mathrm{g})$, while $\mathrm{Ka}$ is adsorption constant $(\mathrm{L} / \mathrm{mg})$.

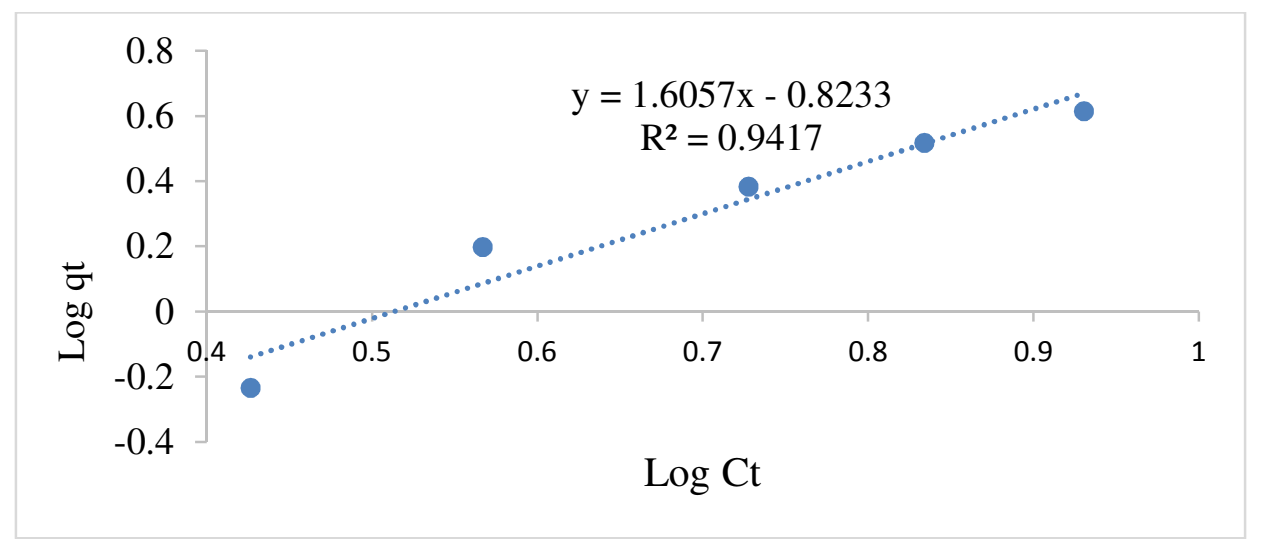

Fig.-5: Freundlich Isotherm Model for Chi-PUF Adsorption of Hg (II) Ions

Figure-5 exhibits the Freundlich isotherm curve with the straight-line equation; $y=1.6057 \mathrm{x}-0.8233$ and $\mathrm{R}^{2}=0.9417$. The above curve was obtained through this equation:

$$
\log q=\frac{1}{n} \log C+\log K_{f}
$$


Where q refers to the number of adsorbates of each adsorbent unit $(\mathrm{mg} / \mathrm{g}), \mathrm{C}$ is the final concentration of the solution $\left(\mathrm{mgL}^{-1}\right), \mathrm{Kf}$ is the adsorption constant $(\mathrm{mg} / \mathrm{g})(\mathrm{L} / \mathrm{mg})$ and $\mathrm{n}$ is adsorption intensity constant. The comparison between Langmuir and Freundlich isotherm from $\mathrm{Hg}$ (II) ions adsorption by Chi-PUF can be observed in Table-1.

Table-1: The result of Langmuir and Freundlich Isotherm Models of Chi-PUF Adsorption of $\mathrm{Hg}$ (II) Ions

\begin{tabular}{c|c|c|c|c|c}
\hline \multicolumn{3}{c|}{ Langmuir Isotherm } & \multicolumn{3}{c}{ Freundlich isotherm } \\
\hline $\mathrm{q}_{\mathrm{m}}(\mathrm{mg} / \mathrm{g})$ & $\mathrm{K}_{\mathrm{a}}$ & $\mathrm{R}^{2}$ & $\mathrm{~K}_{\mathrm{f}}$ & $\mathrm{n}$ & $\mathrm{R}^{2}$ \\
\hline 1.840 & 0.989 & 0.8882 & 0.2968 & 0.6228 & 0.9417 \\
\hline
\end{tabular}

Note: $q_{m}(\mathrm{mg} / \mathrm{g})$ is the maximum adsorption; $\mathrm{K}_{\mathrm{a}}$ is Langmuir constant; $\mathrm{R}^{2}$ is the coefficient of regression; $\mathrm{K}_{\mathrm{f}}$ is Freundlich constant; and $\mathrm{n}$ is adsorption number

According to Table-1, the value of Freundlich isotherm $R^{2}(0.9417)$ is close to 1 compared to the value of Langmuir isotherm $\mathrm{R}^{2}$ (0.8882). Hence, it concluded that the Chi-PUF $\mathrm{Hg}$ (II) ions removal is fit with the Freundlich isotherm model ${ }^{22}$. Freundlich isotherm model uses the assumption in which the binding sites of the adsorbent surface possess the different amount of energy, thus the binding sites are not homogenous. That can be understood because Chi-PUF has different binding sites from PUF matrix and chitosan filler which are heterogenous in nature.

Table-2: A comparison of Chi-PUF with Other Adsorbents from Different Researches

\begin{tabular}{c|c|c|c}
\hline No. & Adsorbent & $\mathrm{Kf}(\mathrm{mg} / \mathrm{g})$ & Reference \\
\hline 1 & $\begin{array}{c}\text { Polypyrrole-chitosan (Ppy/CTN) } \\
\text { nanocomposite }\end{array}$ & 2.3989 & $\begin{array}{c}\text { Salahi and } \\
\text { Ghorbani }^{19}\end{array}$ \\
\hline 2 & $\begin{array}{c}\text { Cationic surfactant cetyltrimethyl } \\
\text { ammonium bromide impregnated } \\
\text { mesoporous carbon (CTAB-MC) }\end{array}$ & 14.5 & \multirow{2}{*}{$\begin{array}{c}\text { Anbia and } \\
\text { Mahmoodi }\end{array}$} \\
\hline 3 & $\begin{array}{c}\text { Anionic surfactant sodium dodecyl } \\
\text { sulfate impregnated mesoporous carbon } \\
\text { (SDS-MC) }\end{array}$ & 17.6 & \multirow{2}{*}{$\begin{array}{c}\text { Faulconer and } \\
\text { Mazyck }^{21}\end{array}$} \\
\hline 5 & Activated carbon surface oxygen & 0.86 & \multirow{2}{*}{ This research $^{2}$} \\
\hline
\end{tabular}

Adsorption constant in the Freundlich isotherm model $\left(\mathrm{K}_{\mathrm{f}}\right)$ was calculated based on the value of slope and intercept which were obtained from the curve in Figure 4. The obtained $\mathrm{K}_{\mathrm{f}}$ value is $0.2968(\mathrm{mg} / \mathrm{g})(\mathrm{L} / \mathrm{mg})$. The value is lower compared to the other adsorbents from different researches as given in Table- 2 . Nevertheless, Chi-PUF's adsorption capability is the potential to be improved. One of which is by optimizing the synthesis material monomers or through an activation process ${ }^{23,7}$.

The interaction power between the adsorbent and the metal ions can be described by $n$ value in Freundlich isotherm. The adsorption process can be assumed to be physical when $n$ is less than $1(\mathrm{n}<1)$. However, when $n$ is more than $1(\mathrm{n}>1)$, chemical adsorption is assumed to be occurred ${ }^{24}$. The value of $\mathrm{n}$ which was obtained in this research is less than $1(\mathrm{n}=0.6228)$ which signifies that the process happened physically. However, a simple procedure to evaluate interaction power between the adsorbent and the adsorbate was conducted by inserting the used adsorbent into an Erlenmeyer filled with aqueous solution and place it onto ultrasonicator to separate the adsorbates from the adsorbent. After being left 24 hours, the Mercury (II) ions concentration was obtained using AAS analysis. The results showed only $14 \%$ of the Mercury (II) ions were separated out of the adsorbents which were insignificant for the interaction between the adsorbate and the adsorbent to be considered based on physical interaction. Thus, $\mathrm{n}$ value in the Freundlich isotherm model cannot be a good representation to describe the interaction power for this research. 
RASĀYAN J. Chem.

Vol. 12 | No. 2 |494 - 501| April - June | 2019

\section{Adsorption Test on Well Water Samples}

The test result of $\mathrm{Hg}$ adsorption by Chi-PUF in the well water samples can be observed in Table- 3 . Three well water samples were obtained from three different coordinate points, each of them was labeled as A, $\mathrm{B}$, and C. Initial concentration of sample A, sample B and sample C using AAS analysis respectively are $4.930 \mathrm{ppb}, 0.955 \mathrm{ppb}$ dan $0.702 \mathrm{ppb}$. The depleted $\mathrm{Hg}$ concentration after the adsorption respectively are $80.072 \%, 83.049 \%$ and $33.680 \%$ with each adsorption capacity of $0.987 \mathrm{mg} / \mathrm{g}, 0.198 \mathrm{mg} / \mathrm{g}$ and 0.059 $\mathrm{mg} / \mathrm{g}$.

Table-3: The Hg Adsorption Test Result of a Well Water Sample from Aceh Jaya Regency by Chi-PUF Adsorbent

\begin{tabular}{|c|c|c|c|c|c|c|}
\hline No. & Sample & Sampling coordinate point & $\begin{array}{c}\mathrm{Co} \\
(\mathrm{ppb})\end{array}$ & $\begin{array}{c}\mathrm{Ct} \\
(\mathrm{ppb})\end{array}$ & $\mathrm{q}(\mathrm{mg} / \mathrm{g})$ & $\operatorname{Pr}(\%)$ \\
\hline \multirow{2}{*}{1.} & \multirow{2}{*}{ Sample A } & $4^{\circ} 29^{\prime} 25^{\prime \prime} \mathrm{LU}$ & \multirow{2}{*}{4.930} & \multirow{2}{*}{0.982} & \multirow{2}{*}{0.987} & \multirow{2}{*}{80.072} \\
\hline & & $95^{\circ} 48^{\prime} 11^{\prime \prime}$ BT & & & & \\
\hline \multirow{2}{*}{2.} & \multirow{2}{*}{ Sample B } & $4^{\circ} 37^{\prime} 36^{\prime \prime} \mathrm{LU}$ & \multirow{2}{*}{0.955} & \multirow{2}{*}{0.162} & \multirow{2}{*}{0.198} & \multirow{2}{*}{83.049} \\
\hline & & $95^{\circ} 40^{\prime} 17^{\prime \prime}, \mathrm{BT}$ & & & & \\
\hline \multirow{2}{*}{3.} & \multirow{2}{*}{ Sample C } & $4^{\circ} 54^{\prime} 50^{\prime \prime} \mathrm{LU}$ & \multirow{2}{*}{0.702} & \multirow{2}{*}{0.466} & \multirow{2}{*}{0.059} & \multirow{2}{*}{33.680} \\
\hline & & $95^{\circ} 28^{\prime} 06^{\prime \prime} \mathrm{BT}$ & & & & \\
\hline
\end{tabular}

Note: Co is the initial AAS-detected Hg concentration (ppb); Ct is the final AAS-detected Hg concentration (ppb); $\mathrm{q}$ is the adsorption capacity $(\mathrm{mg} / \mathrm{g})$; and $\mathrm{Pr}$ is the removal percentage (\%).

The highest adsorption capacity was obtained from $\mathrm{Hg}$ adsorption of sample $\mathrm{A}$ where the $\mathrm{Hg}$ initial concentration is the highest. The different obtained values of adsorption capacity are most probably due to the different amount of adsorbate competitions in each of the water well samples so that affect the ChiPUF's ability to adsorb $\mathrm{Hg}$ (II) ions ${ }^{6}$.

\section{CONCLUSION}

A further investigation on Chi-PUF ability to adsorb $\mathrm{Hg}$ (II) ions and its direct application in the well water samples from Aceh Jaya regency concludes its high potential to be used as an effective adsorbent, especially due to its cheap production and the availability of castor oil as the polyol source. Chi-PUF best performance can be observed when the $\mathrm{pH}$ of the solution is 7 for 60 minutes contact time. The adsorption of Chi-PUF adsorbent against Hg (II) ions was observed to fit the Freundlich isotherm model where its $\mathrm{R}^{2}$ value is closest to $1(0.9417)$ as opposed to Langmuir isotherm where its $\mathrm{R}^{2}$ model is only 0.8882. In comparison to other adsorbents, Chi-PUF is considered to have the lowest adsorption capability. Nevertheless, Chi-PUF was shown to be effective when being introduced into the well water samples collected from Aceh Jaya regency (a location where the $\mathrm{Hg}$ pollution takes place). This effectiveness can be observed through the depletion of $\mathrm{Hg}$ concentration after the adsorption which are $80.072 \%, 83.049 \%$ and $33.680 \%$ from the respective well water samples and adsorption capacity of $0.987 \mathrm{mg} / \mathrm{g}, 0.198 \mathrm{mg} / \mathrm{g}$ and $0.059 \mathrm{mg} / \mathrm{g}$ respectively.

\section{ACKNOWLEDGMENT}

We would like to express our deep gratitude to the Directorate of Research and Community Service for their valuable grant Number 105/SP2H/LT/DPRM/IV/ 2017.

\section{REFERENCES}

1. http://aceh.tribunnews.com/2014/02/19/62-sumur-warga-tercemar-merkuri

2. K. Hasni, Lentera.,15(15), 41(2015).

3. C.H. Xiong, Q. Jia, X.Y. Chen, G. T. Wang andC.P. Yao, Ind. Eng. Chem. Rep, 52(1), 4978(2013). DOI: $10.1021 / \mathrm{ie} 3033312$

4. H. Hong, J. S. Lim, J. Y. Hwang, M. Kim, H. S. Jeong, M. S. Park, 195(1), 136(2018), DOI: 10.1016/j.carbpol.2018.04.081 
RASĀYAN J. Chem.

Vol. 12 | No. 2 |494 - 501| April - June | 2019

5. S. Soriano and R. J. Casella, Journal of the Brazilian Chemical Society, 24(7), 1172(2013), DOI: 10.5935/0103-5053.20130151

6. P.Liu and C. Guo-Feng,Porous Materials: Processing and Application $1^{\text {st }}$ ed. Elsevier, USA,p.345,383(2014).

7. T. A. Khan, M. Nazir, A. E. Khan and U. Journal of Molecular Liquids., 212(1), 467(2016), DOI: 10.1016/j.molliq.2015.09.036

8. E. A. Moawed, M. A. El-Hagrasy, and N. E. M. Embaby, Journal of the Taiwan Institute of Chemical Engineers,70(1), 382(2016), DOI: 10.1016/j.jtice.2016.10.037

9. T. Riaz, A. Ahmad, S. Saleemi, M. Adrees, F.Jamshed, A. M. Hai and T. Jamil,Carbohydrate Polymers, 153(1), 582(2016), DOI: 10.1016/j.carbpol.2016.08.011

10. Darmadi, I. Mustafa, M. Iqhrammullah, Marlina and M. RLubis, Jurnal Bahan Alam Terbarukan, 7(1), 18(2018), DOI: 10.15294/jbat.v7i1.13614

11. A. A. Dulazi and H. Liu, 2012, Application of Chitosan in Environmental Engineering, in: G. Mackay and Jennifer M. Tair (Eds), Handbook of Chitosan Research and Application: Biotechnology in Agriculture, Industry, and Medicine, Richard Nova Science Publishers, New York pp 28-41.

12. F. B. Hussein. Thesis, Department of Chemical Engineering, University of Wisconsin, Milwaukee (2016).

13. L. Kong, F. Qiu, Z. Zhao, X Zhang., T. Zhang, J. Pan and D. Yang, Journal of Cleaner Production, 137(1), 51(2016), DOI: /10.1016/j.jclepro.2016.07.067

14. M. L. Pinto, J. Pires, A. P. Carvalho,M. B. de Carvalho and J. C. Bordado,Microporous and Mesoporous Materials, 89(1), 260(2006), DOI: 10.1016/j.micromeso.2005.10.035

15. M. Kumar and R. Kaur, International Journal of Scientific Research and Reviews, 2(1), 29(2013).

16. S. Huang, C. Ma, Y. Liao, C. Min, P. Duand Y. Jiang, Journal of Nanomaterials. 2016(1), 1(2016). DOI: $10.1155 / 2016 / 7245829$

17. M. M. Goes, M. Keller, V. M. Oliveira, L. D. G. Villalobos, J. C. G. Moraes and G. M. Carvalho, Industrial Crops and Products, 85(1), 149(2016), DOI: 10.1016/j.indcrop.2016.02.051

18. B. Sivakumar, M.Vijayalakshmi, and A. B. Rajendran, RASĀYAN J. Chem., 11(2), 709(2019), DOI: 10.31788/RJC.2018.1123018

19. J. L. Álvarez, M. J. Bastidas, L. Giraldo, P. Rodríguez-Estupiñán and J.C. Moreno-Piraján, RASĀYAN J. Chem., 11(2), 780(2018), DOI: 10.31788/RJC.2018.1122095

20. S. Salahi and M. Ghorbani, Advances in Polymer Technology, 33(1),1(2014), DOI: 10.1002/adv.21428

21. M. Anbia, and S. Amirmahmoodi, Arabian Journal of Chemistry, 9(1), S319(2016), DOI: 10.1016/j.arabjc.2011.04.004

22. E. K. Faulconer and D. W. Mazyck, Journal of Environmental Chemical Engineering, 5(3), 2879(2017), DOI:10.1016/j.jece.2017.05.036

23. H. J. Rao, P. King, and Y. P. Kumar, RASĀYAN J. Chem., 11(3), 1376(2018), DOI: 10.31788/RJC.2018.1134035

24. Marlina, Saiful, Rahmi, S. Saleha and S Nurman, Orient. J. Chem., 33(1), 199(2017), DOI: $10.13005 / \mathrm{ojc} / 330122$

25. W.L. Chou, C.T. Wang, W.C. Chang, and S.Y. Chang, Journal Hazardous Material, 180(1), 217(2010), DOI: 10.1016/j.jhazmat.2010.04.017

[RJC-5080/2018] 